\title{
Marriage as Ruse or Migration Route: Jewish Women's Mobility and Sex Trafficking to Argentina, 1890s-1930s
}

\author{
Mir Yarfitz, Wake Forest University, Winston-Salem, North Carolina, USA
}

\begin{abstract}
The victim narrative of the international anti-white slavery movements of the late nineteenth and early twentieth century highlighted the suffering of prostituted women entrapped by violent men. Due to both antisemitic exaggeration and the reality of Ashkenazi Jewish networks of international sex work management in this period, Jews faced particular scrutiny as traffickers, and organized internationally with non-Jewish reformers against the phenomenon. Reformers often decried the shtile khupe, a Jewish religious marriage ceremony without a civil component, as a key trafficking technique. Drawing on League of Nations archives, court records, and the Yiddish, Spanish, and English press, this essay provides a granular social history of marriage and associated relational strategies for cross-border migration and structuring Jewish sex work on the ground in early-twentieth-century Buenos Aires. Evidence from sex workers and their managers pushes against these victimization narratives, reframing marriage as a method to achieve transnational mobility and improve labor and living conditions. Historical and contemporary feminist responses to trafficking share rhetorical strategies and critiques - in both past and present, transnational sex work can be analyzed in a migratory rather than coercive context, centering individuals making difficult choices from among limited options.
\end{abstract}

\footnotetext{
There suddenly arrives in a[n Eastern European] village a compatriot who has made a fortune in Argentina... One week is sufficient to select his prey and lock down a relationship with her. The family vacillates. But the same suitor makes a donation to the father or the mother... For the girl, the arrival of the traveler symbolizes the fulfillment of all her dreams and illusions forged while she devoted her days to heavy labor. This is her liberation... [But when the true nature of the ruse is revealed, that this man is a trafficker in women,] the women who have fallen into the trap deal with their pain alone. ${ }^{1}$
}

This story of young Ashkenazi Jewish women's entrapment into the international sex industry, printed in an Argentine provincial newspaper in 1930, reflected narrative tropes by then familiar for four decades on both sides of the Atlantic. ${ }^{2}$ A perceived crisis of "white slavery" or "traffic in women" during the mass migrations of the late nineteenth and early twentieth centuries stirred the popular press and social activists in Europe and the Americas to respond to a major rise in the cross-border movement of women for sexual purposes. ${ }^{3}$ Tales of white slaves, young European victims of swarthy male exploiters who fooled or forced them into brothels across international borders, circulated in newspapers, books, and organizational propaganda. Self-styled white slavery abolitionists drew language from the abolition movement against black slavery. From transnational women's rights groups to the League of Nations, these groups opposed the public health regulatory regimes that legalized prostitution in many countries, and proposed restrictions on international 
mobility, primarily for suspicious and vulnerable groups. The Argentine capital of Buenos Aires became a flashpoint for these controversies, where European immigration fueled explosive growth and supported a half-century of government-regulated brothels. ${ }^{4}$ Europe's wandering ur-Others, the Jews, already suspect as avaricious and engaged in secret multi-national conspiracies, made up the collectivity most often blamed for the entrapment of innocent women.

Ashkenazi Jews became highly visible as sex traffickers in multiple parts of the world in the late nineteenth and early twentieth century, particularly in South America. The Spanish term polaca, referring to immigrant women from Poland or Eastern Europe more broadly, in this context implicitly Jewish, became a common general word for prostitute in Argentina and Brazil across the twentieth century. Displacement of blame for trafficking onto the Jews stretched from the British white slavery panic of the 1880 s to the Nazi claim that Jews were responsible for ninetyeight percent of the international sex trade. ${ }^{5}$ The antisemitic construct of the Jew as hidden conspirator and unscrupulous economic exploiter of white Christians has a long history and persists to this day. Accusations of parasitism, mistreatment of workers, and slum-lordism resonated with the image of the Jewish pimp and brothel owner. Although antisemites and nativists exaggerated Jewish masterminding of white slavery, transnational networks of Ashkenazi Jews did in fact play an important role in this era in transporting women for sexual purposes across national borders. ${ }^{6}$

Jews were certainly not the only immigrants in Buenos Aires managing places of assignation, but they were the most tightly organized and collectively identifiable. During the massive migrations out of Europe, Argentina became even more a land of new immigrants than the United States. The capital city boomed with mostly male immigrants and export-led economic development during its "golden age," roughly 1890 to 1913 , and became a world-famous city of sin, where the tango emerged from legal bordellos that housed thousands of foreign-born sex workers. Their clients, mostly Southern European immigrant laborers, mingled in the brothels and homosocial spaces immortalized in tango lyrics. ${ }^{7}$ From the 1890 s, when Eastern European Jews first began to arrive in substantial numbers in Argentina, sex workers and their managers made up a large and highly visible percentage of this community's population. ${ }^{8}$ While precise numbers of sex workers and Jews more generally cannot be established, between twenty and upwards of thirty

Women in Judaism: A Multidisciplinary Journal Volume 17 Number 1 (2020) 
percent of registered prostitutes in Buenos Aires across the period from 1899 to 1924 were probably Jewish, a substantially higher number than that of the Jewish population percentage in the city as a whole. ${ }^{9}$ Jewish visibility in sex work was particularly high in the early years of the community's local formation: 1895 census data show 229 Jewish prostitutes in the city's registered brothels, and police records for the preceding two years show 164 Jewish men arrested for pimping, although there were only 753 Jews counted among the 663,854 residents of Buenos Aires. $^{10}$

Jews engaged in managing sex work in Argentina created a long-standing formal organization to defend their interests: the Buenos Aires-based Varsovia Israelite Mutual Aid and Burial Society. ${ }^{11}$ At its peak of power and visibility in the $1920 \mathrm{~s}$, the Society had over four hundred members on its rolls, all of them likely to have been pimps, madams, brothel-owners, prostitutes, and traffickers in women. Members circulated loans to develop properties into brothels throughout the Argentine capital and in other provinces. They outfitted a lavish mansion on the capital's prestigious Cordoba Avenue as a headquarters to host meetings, parties, and religious services. The mansion included a synagogue, since the larger Jewish community refused to allow Society members into its spaces of worship. In 1930, the Society was legally dissolved through a dramatic court case, spearheaded by a local judge and the police chief of the main Jewish neighborhood. One hundred and twenty Varsovia Society members were arrested in coordinated police sweeps, while the three hundred others sought, apparently forewarned, could not be found. Although the liminal legality of prostitution meant that only a small number of members remained imprisoned beyond a few months, Jews would not return to their influential position in transnational sex work or the Argentine underworld. The Society's mansion was turned over to the Department of Education, and the entire system of regulated prostitution was soon dismantled. ${ }^{12}$

\section{Narratives of the Shtile Khupe's Dangers}

The story of marriage as a brothel recruitment technique excerpted above was published in the Argentine province of Santa Fe during the 1930 court case against the Varsovia Society, as part of a widely advertised serial interview with Arnold K., supposedly a former member. The reporter quotes Arnold K. extensively as an inside source on the organization's methods of entrapment, cross-border transit, and work structure. Although Arnold K.'s organizational involvement or 
actual existence cannot be verified, and the sensationalized framing and clichéd content of his story draw its veracity into question, the resonance of his tale with other narratives is itself useful to explicating then-current discourses around Jewish sex trafficking, if not actual practices. ${ }^{13}$ His story reflects common elements of white slave stories, as well as a twist uniquely associated with Jewish management of sex trafficking: the marriage ruse.

In the reporting of Arnold K.'s story, as in similar versions circulated by international reformers, the white slave's journey began with her wedding. A well-dressed young man would arrive in a village and sweep the beautiful young woman and her naïve parents off their feet. After a rapid wedding, the newlyweds would depart for a bright future overseas. Once out of familial reach, however, the trafficker's true intentions would become clear. Either on the transatlantic journey or once deposited into a jail-like brothel, the deception of the marriage would be revealed, and the deflowered virgin would be abandoned by her "husband," trapped by distance and language, and forced to submit to ongoing sexual exploitation. The marriage itself would provide no legal protections to the bride, but she could not remarry Jewishly without her husband's provision of a "get," or religious divorce. In international conversations around trafficking, this strategic usage of marriage as a form of entrapment was only associated with Jews. ${ }^{14}$ The particular association of the sham marriage method with Jews was so tight that the Argentine Yiddish press sometimes referred to local-level Jewish pimps as "grooms" and their associated prostitutes as "brides." 15

Because a Jewish marriage certificate (ketubah) lacked civil weight, reformers feared traffickers could exploit religious marriage as a strategy. Eastern European authorities and Jewish community leaders were particularly concerned with the risks of what was generally referred to as the shtile khupe, literally, "discreet wedding canopy" or "silent marriage" in Yiddish. The Jewish wedding that complied with rabbinic but not civil law was debated on both sides of the Atlantic, as men could "marry" a woman (or several) in Europe, take her to the other side of the world, and be free of any binding legal responsibility upon arrival. European reformers also worried that in addition to facilitating the entrapment and international transit of women, marriage could keep unwilling women in prostitution - husbands might act as pimps to unwilling wives, using the stigma of divorce and abandonment as leverage. Local and international anti-prostitution activists

Women in Judaism: A Multidisciplinary Journal Volume 17 Number 1 (2020) 
advocated for harsher punishment of men who lived on their wives' immoral earnings, particularly as this might mean a wife working to support an unproductive husband. Argentine reformers tried to prevent immigrant women arriving alone at the port from disembarking to meet suspicious “"bridegrooms-to-be,' accompanied as a rule by venerable-looking but temporary parents."16

Muckracking journalists around the world identified marriage as a technique of Jewish traffickers in particular. In the 1927 international bestseller Road to Buenos Ayres, French journalist Albert Londres describes a trip to Poland in which he explains how Jewish procurers negotiate false marriage contracts with the families of attractive, impoverished girls in their late teens and early twenties, often on the recommendation of matchmakers whom they pay year-round for the privilege. ${ }^{17}$ The marriage ruse appeared for several decades in stories linking Jews and the international traffic in women. In 1907 a series of widely read articles published in McClure's emphasized the Jewish role in organized prostitution in the United States, particularly in Chicago. ${ }^{18}$ Attractive Jewish men lured young women with "promises of an easy time, plenty of money, fine clothes and the usual stock of allurements - or a fake marriage... In some instances the hunters really marry the victims." 19 The Los Angeles Times repeated news from the Jewish press under the title "Jewish Girls are Sacrificed": "Some [procurers] seek the company of Jewish maidens with avowed intention of honorable marriage. Others actually marry the girls and then force them to lead dissolute lives." ${ }^{20}$ The US government's immigration report of 1911 also cited marriage as a method of entrapment among Jewish procurers in particular: "There are large numbers of Jews scattered throughout the United States who seduce and keep girls...by the methods already indicated - love-making and pretenses of marriage - they deceive and ruin." ${ }^{21}$ Charges of immorality and criminality against Eastern European Jews, and other suspicious immigrant groups, could encourage popular hostility as well as migration restriction.

The shtile khupe was thus a frequent trope in narratives of Jewish involvement in transnational sex trafficking as told by Jews and non-Jews around the world between the late nineteenth century and the interwar period. During this era, Ashkenazi Jews were indeed involved in the circulation of sex workers across international borders, particularly to Argentina, and marriage was a common element of this phenomena, but often in ways beyond the coercive framing of the white slave and shtile khupe stories. Narratives of white slavery and the shtile khupe

Women in Judaism: A Multidisciplinary Journal Volume 17 Number 1 (2020) 
ruse emerged in the context of larger anxieties and agendas tied to cultural and population shifts, and were deployed by both Jewish and non-Jewish reformers to multiple ends. Evidence from sex workers and their managers pushes against these victimization narratives, presenting marriage as a form of transnational mobility and economical labor structure. This version, while less palatable, lines up with much of the contemporary scholarship on sex work that highlights women's agency. The narrative association between religious marriage and Jewish sex trafficking should not be seen as evidence that trafficking usually began with a sham marriage, but that the tension between religious and civil marriage was a useful flashpoint in a constellation of interlocking issues in a time of transnational mobility.

\section{Marriage Anxieties and Reformers' Responses}

The principal source for most historians who link Jews and prostitution has been Edward Bristow's 1983 transnational historical analysis Prostitution and Prejudice: The Jewish Fight against White Slavery, 1870-1939.22 Scholars have cited Bristow's work as proof that the shtile khupe made women vulnerable not only to desertion but also to being trafficked as white slaves. ${ }^{23}$ However, examination of the primary sources for Bristow's discussion of the shtile khupe as a tactic of white slavers shows that his argument reflects the concern expressed by reform organizations such as the London-based international Jewish Association for the Protection of Girls and Women (JAPGW) rather than external evidence for the existence of coercive traffic. Like most scholarship which has acknowledged Jewish participation in international prostitution between the 1890s and 1930s, Bristow's work includes an element of seeking to absolve Jews as a whole for responsibility by highlighting the energetic fight of Jews around the world against these rogue elements. While Bristow's book is based on an impressive range of multi-lingual and multi-continental archival materials, and was transnational before the term was coined, he cites no documentary evidence that the phenomena of prostitution and unregulated marriage are causally linked. Keely StauterHalsted notes that Bristow and other scholars report "uncritically" on this linkage. ${ }^{24}$ Despite extensive concern over unregulated Jewish marriages in general and potential links to sexual trafficking in particular, Jewish social welfare organizations presented anecdotal evidence of causality, with few incidents of successful rescue to show for their extensive efforts. Instead, warnings about the risks of the shtile khupe can be understood to encapsulate broader anxieties

Women in Judaism: A Multidisciplinary Journal Volume 17 Number 1 (2020) 
around migration and changes in the institution of marriage itself, as well as a different kind of causal connection between marriage and cross-border prostitution. Shtile khupe stories reflected modern changes in courtship, marriage practices, and family economies in the Ashkenazi diaspora and secularizing societies. ${ }^{25}$

Jewish anti-trafficking reform organizations raised the dangers of the shtile khupe across several decades. At the JAPGW's 1910 international conference in London, Samuel Cohen, the organization's head, reported to the assemblage:

Many cases have come under my observation during the last six years of girls who have been led astray by looking upon the 'Kesubah' [Jewish marriage contract] of the 'Stille Chupe' as a legal document, and one man will make use of such a 'Kesubah' with different girls for his nefarious purposes. I was at Southampton a few weeks ago, watching a steamer which was to sail for South America, and there I saw a Jewish girl.... a man appeared, producing the 'Kesubah,' and saying 'This is my wife, here is the Kesubah.'...I was quite satisfied from his contradictory answers that he was trafficking her. ${ }^{26}$

Cohen reflected the reform organization's tendency to surveil women outside of their "proper place," policing poor women's mobility and sexual agency for their own good. Twenty years later, as portrayed in the Argentine Yiddish press, the same Samuel Cohen, still in his leadership position with the JAPGW and a member of the League of Nations' coordinating committee of the "Special Experts" investigation into trafficking, visited Buenos Aires in the wake of the Varsovia Society court case and spoke on the subject with members of the JAPGW's Argentine branch and the Immigrant Protection Society. Cohen complained that the shtile khupe was one of several religious idioms commonly deployed by traffickers, but the particular visibility of Jewish religious modalities fed the League's inaccurate perception that the Jews controlled the entire worldwide traffic in women. ${ }^{27}$ Like the JAPGW, Yiddish publications often presented Jewish women's vulnerability to trafficking as a metaphor for the vulnerability of the Jewish community at large to antisemitism, not far removed from European pogroms and the building xenophobia of local nationalist movements.

As Jewish populations and patterns shifted in the nineteenth century, religious and secular authorities, along with cultural producers, reflected and grappled with popular fears about sexuality and family formation. Civil marriage was not common in Eastern Europe in the nineteenth century, and thus Ashkenazi Jews rarely considered this option. Ritual marriage without a civil component was particularly pervasive among poor families seeking to avoid related

Women in Judaism: A Multidisciplinary Journal Volume 17 Number 1 (2020) 
taxation. ${ }^{28}$ In Eastern Europe, poorer Jews usually married in a short ceremony in a private house, sometimes but not always in the presence of a rabbi or other religious officiant. The minimal requirement for a religious marriage was that the groom put a ring on the bride's finger while saying a ritual consecration phrase in Hebrew in the presence of two adult Jewish men. The witnesses would sign the ketubah, but it would not be put on any official record. Although Eastern European governments engaged rabbis as agents of the state, they had little effect on Jewish marriage practices in this period. ${ }^{29}$ While ritual marriage would not be recognized as legally valid across international boundaries, it saved families money and reduced exposure to the state. ${ }^{30}$

Polish authorities, concerned with their region's reputation as a recruiting ground for the international traffic in women, highlighted Jewish religious marriage practices as a causal factor, thus shunting responsibility to other realms. The shtile khupe became a rhetorical focus for efforts to increase state control over religious authority, an effort parallel to that previously made by the imperial Russian state. In a proposal submitted to the 1927 International Congress on the Subject of the Suppression of Traffic in Women, the Polish National Committee for the Suppression of Traffic in Women and Children argued that religious marriage gave Jewish traffickers an advantage over other groups in recruiting women for prostitution:

Even the presence of a Rabbi or another official representative is not required; any Jew can be a witness.... The Jewish ritual secret weddings are conducive to the traffic in women... the unscrupulous husband in order to get rid of his wife, can take her abroad and sell to some brothel [sic] without losing the possibility of contracting new religious weddings, because for the aforesaid reasons, his private documents do not mention any previous marriage. As it is, the traffickers, especially in Jewish communities, have more opportunity for carrying on their trade than in other communities, due entirely to the ritual weddings. ${ }^{31}$

The Polish government thus articulates marriage for sex work recruitment as a particularly Jewish practice, blaming the Jews for Polish involvement in international sex trafficking. ${ }^{32}$ Polish reformers proposed to solve the problem created by Jewish marriage practices through increasing state oversight. Jewish women married ritually would be legally considered concubines, not wives. While not a violation of Polish (or other European) law at the time, this did expose women to financial and social risk. Reformers argued this would be easily solved if "Jewish clergy and intellectual classes" would give up this custom, and Rabbis register all weddings with civil authorities. ${ }^{33}$ This proposal called for an increase of the penetration of the Polish state into Jewish life.

Women in Judaism: A Multidisciplinary Journal Volume 17 Number 1 (2020) 
Globally, Jewish community leaders deployed related strategies to police these issues. Jewish reformers worried that the sacramental formula could be performed by "any Jew in the street," and proposed tighter Rabbinic control. ${ }^{34}$ Rabbis should formalize all Jewish marriages, and be responsible for registering them with civil authorities. The formal recommendations proposed at the 1927 London international conference of the JAPGW urged all rabbis around the world (including Chasidim, generally more separate from secular matters) to become more involved in the prevention of the shtile khupe marriages: "it is to be suggested to Rabbis and others holding responsible positions in the Jewish communities to discourage the continuance of such marriages to the utmost of their powers... [They] should require young men and women, who come to them for the purpose of marriage, and who have been born in a foreign country, to produce evidence that there is no legal impediment to the proposed marriage." ${ }^{35}$ Religious authority would thus be more powerfully brought into family decisions. Parents and guardians were also to be strongly warned "of the grave dangers which may threaten their daughters' future welfare unless strict enquiries are made concerning young men who propose to marry them, and of whose antecedents they know but little or nothing." 36 Existing local JAPGW branches or committees would make these inquiries, engaging "the cooperation of Rabbis and others to warn parents against such marriage brokers (Schadchen), whose object may be only to make money, and who are often the accomplices of the traffickers." 37 The risks of unknown men and marriage brokers from outside local community networks would thus be counterbalanced by greater involvement of rabbis and social organizations in families' decisions.

On the ground in Argentina, reformers attempted these and similar approaches. In 1924, League of Nations investigators reported on Argentine efforts to regulate the entry of women being brought to the country with promises of marriage to men met for the first time at the Buenos Aires port: "Girls coming to be married are not allowed to leave the docks until the marriage has taken place and this marriage is only solemnized when an investigation by the police reveals that fact that the man in question is a respectable person." 38 The marriage ruse featured prominently in public discourse around the 1930 legal breakup of the Varsovia Society as an explanation for how the group had coordinated the importation and ongoing exploitation of woman in Argentina on such a large scale. By 1932, the Buenos Aires branch of the JAPGW collaborated with the Polish 
consul and other organizations in Argentina to "safeguard young girls arriving for the purpose of marriage. Every application for a permit of entry for a fiancée must be accompanied by a sum of money to enable the civil marriage to take place immediately on arrival, and in the presence of our officer... [to prevent the possibility] that the young man suggests cohabitation without marriage, for the purpose of driving the girl to a life of immorality." ${ }^{39}$ Later in the 1930s, this organization required that prospective brides and grooms provide rabbis with premarital morality certificates, to try to protect the reputation of the local Jewish community's future generations. ${ }^{40}$

Immigration laws and border enforcement enacted in Argentina and in Europe in the first decades of the twentieth century often responded to international anti-trafficking activism by restricting entry of single and minor women. ${ }^{41}$ The French and Spanish governments would not grant passports to minor women, unless they were married. ${ }^{42}$ Investigators, like those of the League and other international organizations, often focused on minors as unequivocal victims of exploitation. Marriage, or documents reflecting this status, became the predominant strategy for evading this surveillance focus. It smoothed the travel of minor women to and from many locations; as a madam in Marseilles told the League investigator "All the bunch that I know, marry their girls. If the girl is young, you then have no trouble." 43 In the words of one pimp interviewed in France, "I am married. I can take my wife any place I want; no matter what her age is." ${ }^{4}$ In Genoa, a local prostitute and pimp explained to the investigator how a "friend" would best transport an Italian minor: they should travel first or second class, and use a French rather than an Italian passport, which they can get "fixed" for Argentina by the Italian Consul in Marseilles. ${ }^{45}$ Before laying out this system, however, the Genoan sex worker tells him the easiest route from there to Argentina would be if his friend simply married the Italian minor. While minors, defined in Argentina as under age 22, were discouraged from entering the country and could not legally register as prostitutes, marriage essentially granted minors majority status. The Varsovia Society was accused of a brisk trade in documents with inflated ages as one work-around, in addition to the marriage strategy. ${ }^{46}$ Short-term marriage as a border-crossing strategy for minors did have limits, however, as men who traveled the same route repeatedly with different women became known to officials. A larger network might then be enlisted, as described by a French pimp: "I know a lot of boys who left for Brasil, but they got friends to marry the gals first. Married women

Women in Judaism: A Multidisciplinary Journal Volume 17 Number 1 (2020) 
even under 21 they got to give a pass to" as the "boys [themselves were] already married or too well known themselves." ${ }^{\prime 7}$ If multiple routes were travelled or officials were less observant, many young men appear to have married half a dozen women at different times. ${ }^{48}$

During the mid-1920s immigration policies tightened in many receiving countries. Argentine officials became increasingly strict about passports and other paperwork at the end of 1923, in part inspired by newly restrictive national entry quotas in the United States that aimed to reduce immigration from Southern and Eastern Europe. ${ }^{49}$ The mainstream Jewish community argued in the Buenos Aires Yiddish press against the public association between Jews and the traffic in women, reflecting fear that restrictions would be further tightened for all immigrants. ${ }^{50}$ The details of immigration restrictions inspired various workarounds. The effort to exclude from entry to Argentina women registered in other countries as prostitutes resulted in women finding ways to get their names off the books before getting their passports, making the common shift from registered to clandestine sex work for the necessary period. ${ }^{51}$ Others unable to get required documents attesting to good character entered Argentina over land at less secure borders, disembarking at the less stringent ports of Rio de Janeiro and Montevideo. ${ }^{52}$ As Argentine law 817 required a judicial or police certificate and a health certificate for entry, some people used false documents while others bribed local police in particular ports and transmigration locations. ${ }^{53}$

In the Santa Fe, Argentina, newspaper interview series with ex-Varsovia member Arnold K. presented at the beginning of this essay, neither the subject nor his interlocutor explain why multiple bridegrooms are enlisted to bring groups of women from Eastern Europe to Argentina. ${ }^{54}$ Assessing that narrative in the larger migratory context explains that each woman must travel with her own husband in order to avoid the scrutiny of border and migration authorities looking for young single women who might be in danger of being trafficked. Temporary marriage proved to be a valuable migratory tool. International activism around white slavery increased the scrutiny placed on young single women at many border crossings and ports. The League's investigation paid particular attention to enforcement at these points, criticizing both local officials and national governments for insufficient action. Although the undercover experts sought evidence of corrupt officials knowingly complicit in the traffic of underage and coerced women, they generally found women who had already been in prostitution working together with men to deploy both legal and

Women in Judaism: A Multidisciplinary Journal Volume 17 Number 1 (2020) 
counterfeit travel documents. Ironically, the very immigration and border control restrictions designed to prevent trafficking by scrutinizing women travelling alone pushed women into strategic marriages in order to move under the radar.

\section{Sex Workers Describe Marriage as Migration Strategy}

The victim narrative of the anti-white slavery movements of the late nineteenth and early twentieth century, in which prostituted women are always trapped and taken advantage of by unscrupulous and violent men, corresponds to current anti-trafficking rhetoric. Today, the two principal positions on sex trafficking echo the two predominant arguments made by anti-prostitution activists and some feminists over the past century and a half. The first position, that all prostitution inherently exploits women and should be entirely abolished, initially became globally influential through Josephine Butler's leadership of the opposition to the British Empire's Contagious Diseases Acts from the 1860 s to the $1880 \mathrm{~s}$, which regulated prostitution in the British Empire. ${ }^{55}$ Beginning in the 1970s, "radical feminists" such as Kathleen Barry, Sheila Jeffries, Catharine MacKinnon, and groups like the Coalition Against Trafficking in Women (CATW) updated this position with a new energy and an ideological framework that equated all prostitution and pornography with women's systematic exploitation. ${ }^{56}$ More recent global anti-trafficking or sexual slavery campaigns generally share this orientation on the fundamental victimization of prostitutes with critics of several decades and over a century ago. ${ }^{57}$ Not all feminists agree with this perspective, but it is often interpreted as the only pro-woman or feminist position on prostitution.

In the second position, usually held by "pro-sex" or "sex-positive" feminist opponents of those in the prior camp (whom they dubbed "anti-sex" or "dominance" feminists), and by groups of self-identified sex workers themselves, the risks of prostitution emerge from it being a form of exploited labor, with suggested responses ranging from state regulation to unionization. ${ }^{58}$ Public health advocates in late-nineteenth-century modernizing regimes proposed that the problems linked to prostitution, such as sexually transmitted infections, could be best managed through legal regulation and medical oversight. The Argentine system during this period fell in this category, along with many other systems following the French example. Feminist abolitionists from Josephine Butler onward worried that these regulatory regimes fundamentally restricted prostitutes' agency by forcing them to submit to invasive medical inspections and to stop working 
if diagnosed with syphilis or other infections -- and perhaps be confined inside a "lock" hospital. An alternative argument for decriminalization, based on the idea that prostitution is a form of labor made exploitative by its conditions, was initially voiced in 1909 by Emma Goldman, who compared it to women's oppression in marriage and under capitalism more generally. ${ }^{59}$ Parallel to this defense of legalization, some prostitutes began to organize collectively in the 1960s and 1970s as sex workers, demanding respect as free agents rather than pity as victims. The term "sex work" originated with the political liberation and feminist movements of this era, and spread with public health campaigns related to HIV and AIDS. These activists and their academic supporters have argued that abolitionists deny sex workers agency in their own lives. ${ }^{60}$

Scholars influenced by the latter perspective have recently tried to move beyond a dichotomy of internationally mobile prostitutes as tragic victims or powerful agents, by complicating the idea of consent and putting international trafficking in the context of migration. ${ }^{61}$ Scholar of migration and trafficking Maybritt Jill Alpes argues for the utility of viewing traffickers as "people who facilitate or sponsor a migration process... Even if coercion is exercised... the initial demand for migration has been satisfied." ${ }^{2}$ This framework extends the "modified choice" model, the idea that sex workers make difficult choices out of a limited, less-than-ideal range. This view tries to balance structure and agency and cautions against the romanticization of sex workers' decisions: women's lives must be understood as never permitting total freedom of choice, due to hierarchies of race, sex, and class. ${ }^{63}$ Argentine novelist Mario Szichman imagines a Jewish sex worker's decision-making along these lines, as his recurrent character Dora chooses prostitution as an alternative to hunger: "I discovered that the world belonged to men, and since I could not conquer it with my head, I used my tukhes." ${ }^{4}$ Even beyond economic necessity, sex work can provide a route for women to approximate men's sexual freedom. Some have gone even further than promoting decriminalization, arguing that sex work can be a liberatory practice, enabling a broader range of life, love, and leisure choices than otherwise available. ${ }^{65}$

Whether viewing prostitution as sex work or modified choice, these can be difficult conversations for historians and other scholars to have with current anti-trafficking activists and policy makers, who worry that regulationist and modified choice perspectives minimize the very real day-to-day exploitation of women. People selling sex routinely face violence at the hands of

Women in Judaism: A Multidisciplinary Journal Volume 17 Number 1 (2020) 
pimps, clients, police, and the criminal justice system, and have done so throughout the modern era. Regulationists hope that their proposals can reduce certain aspects of this violence, and advocates of total legalization call for legal and health protection for all workers, while both camps point out that abolitionists have never been successful in enlisting their targets of rescue themselves to their cause. The language of victim and exploiter does reflect sometimes horrifying realities, but as terms of historical analysis, this dichotomy simplifies a complex range of lived experience and erases the agency of people who trade sex for something they need.

Unfortunately, the perspectives of women in sex work often fall out of the sources, smothered by the interpretations of their behaviors and motivations articulated by those recording them. An especially rich and formerly under-utilized resource, the League of Nations' archive in Geneva, holds a massive lode of confidential reports from several years of undercover investigation into international sex trafficking in the mid-1920s, during which investigators sometimes posing as pimps and brothel owners circulated in underworlds from Asia to Latin America. ${ }^{66}$ These papers extensively assess the Argentine underworld as well as dozens of other sites, and sketch global networks of sex work management. Individuals involved at all levels of the transatlantic movement of women for sex work certainly had self-protective incentive to disavow practices targeted by transnational anti-white slavery agreements, and lied egregiously when taken to court about all aspects of their business dealings. ${ }^{67}$ Undercover League investigator Paul Kinzie, through his network of references cultivated over decades, seems to have convinced most of his interviewees that he was indeed one of them, offering multiple versions (in multiple languages, including Yiddish) of his cover story, in which he sought advice on how to best traffic his own woman or women, sometimes minors or unexperienced as sex workers. While his reports tend to elide the voices of female sex workers and dramatize his own exploits, their granular detail is unmatched in other sources, and when read in combination with contemporary Spanish and Yiddish press, legal records, and reform organizations' archives, supports new conclusions about generally invisible social actors.

Unlike the data gathered by other experts and reformers, Kinzie's interviews magnify the voices of managers of sex work, the pimps, brothel owners, and madams who, while close to sex workers and regularly speaking for them, promote their own agendas. Although less moralistic

Women in Judaism: A Multidisciplinary Journal Volume 17 Number 1 (2020) 
than many observers, Kinzie glosses his interviews with sex workers with terms such as "admitting" they "indulged in promiscuous intercourse" before getting paid for sex, but doesn't provide their own words or meanings. ${ }^{68} \mathrm{He}$ doesn't leave room for sex workers to understand themselves as anything other than fallen women, and his own judgments and preferential treatment of male interlocutors erase women's opportunities to voice their own perspectives. He usually gives economic necessity as shorthand for their motivations, such as: "I tried to get work, but the most I can make is 6 francs to 15 francs a day sewing. So I go out three or four times a week and do business." ${ }^{69}$ Although a half-century before the term "sex work" was coined, everyone Kinzie quotes, on both sides of the Atlantic and from the lowest to the highest levels of organization, shared this understanding of prostitution as work, and of themselves as businessmen and businesswomen.

Contrary to the victim narrative, most women engaged with prostitution in a range of ways, not as the degrading life sentence imagined by moral reformers, but to different degrees at different times and in a range of settings. ${ }^{70}$ Anti-trafficking activists from the League of Nations to the JAPGW spent years at the local level hunting down evidence of involuntary traffic, with disappointing results. According to over a hundred League undercover interviews in Buenos Aires with prostitutes, brothel owners, and others in sex work as well as police and officials, "There was agreement, practically amounting to unanimity, that the vast majority of alien women who are now practicing prostitution in Buenos Aires were prostitutes in their home countries and that they came or were brought for that purpose without deceit, fraud, or force being used." interlocutors told Kinzie the same story as did their madams and pimps: they chose to migrate in search of better earnings. ${ }^{72}$ Managers told stories which fit their own agendas, including details to encourage their audience (Kinzie posing as a potential investor) that women did repay over time those who had assisted in facilitating their transit. ${ }^{73}$ Police and immigration officials, aware they were speaking to international investigators, denied any extra-legal activity. Thus, according to those on the ground in this important receiving country, even when pressed by international reformers seeking evidence of traffic, involuntary traffic was a minimal element in global flows of women engaged in sex work in this period. 
Some versions of the marriage ruse story continued beyond initial seduction and transAtlantic journey into local brothel imprisonment, where attachment to a husband might bind a wife to ongoing entrapment. Mainstream Ashkenazi Jewish culture considered the existence of marriage among prostitutes and pimps to invariably be a sham, as represented in Sholem Asch's play "God of Vengeance," in which Schloyme the pimp proposes to a brothel owner that he marry the oldest prostitute in order to set up a brothel of his own. ${ }^{74}$ As the news cycle ramped up in late May around the 1930 court case against the Varsovia Society, the Buenos Aires Herald reported on legal testimony related to the role of marriage in the Society's practices of entrapping and keeping women prisoner: "as a marriage ceremony was performed, no action could have been taken, even supposing suspicion to have been aroused. Once 'married,' the white slavers told their victims what their future occupation would be, and the girls had to choose between possible starvation in a strange land, with a strange language, or careers of infamy."75 In this version of the marriage ruse, marriage tied the victim to her exploiter upon arrival. The prostitution of married women often disturbed reformers more than single women's sex work, as it was more disruptive to middle-class behavioral norms. Husbands were often assumed to have been pressuring their wives and profiting from their sexual labors. The legal summary from the 1930 Varsovia case asserted that most of the Society's members forced their own wives into prostitution. ${ }^{76}$

In another interpretation, according to sex work managers, sex workers had input into these primary partnerships. Wealthy and internationally-networked Buenos Aires brothel owner Max Goldberg explained to Kinzie how the Society would support transfer of a prostitute's primary attachment from one man to another: "You know women; when they are whores, or when they are respectable they are all alike. They like a change too. Of course, the girl must like the man." 77 This suggests that women at least occasionally had choice in changing their managers and primary partners. Although the court case against the Society framed it as obligatory for prostitutes to always have a pimp within the Society, League of Nations investigators acknowledged that the Varsovia Society mediated "if any of them did not wish to live with the men." 78 Experienced traffickers routinely warned Kinzie to be sure his girl would stay with him before making the large investment in bringing her across the Atlantic, underscoring the frequency with which women would move from one man to another. ${ }^{79}$ Keely Stauter-Halsted offers examples from Eastern

Women in Judaism: A Multidisciplinary Journal Volume 17 Number 1 (2020) 
European archives of several cases of women who ended up practicing sex work in Argentina and whose stories demonstrated a range of agential decision-making. ${ }^{80}$ While a marriage in the Old Country might not have been chosen freely by young women, with divorce rare, sex workers in South America could have had the option to choose or change their primary partner, free of stigma within the underworld. Women were probably less naïve than the dominant narrative suggests, and could seek opportunities to switch to preferable partners.

Several decades of historians have demonstrated that coercive sex traffic, sensationalized as white slavery, did not actually exist on the enormous scale publicized in this period, and even many contemporary observers expressed doubt. ${ }^{81}$ The League's failure to find true victims in Argentina, despite years of expensive transnational investigation, paralleled reformers' generally fruitless search in receiving countries for "green girls" or "greenies," women who had not previously practiced prostitution. Sex work managers disavowed the entrapment of greenies as unnecessary, dangerous, and most significantly, not cost-effective. The League's summary of the transit route between Uruguay and Buenos Aires affirmed "Professional prostitutes already trained are regarded as better money makers than amateurs." 82 Candid replies to Kinzie's queries about how to best bring in minors and greenies (as overlapping or distinct categories) were nearly always met with the suggestions that he marry the minor and forget about the green girls, as their low profit potential and the risk of their escape would not guarantee a return on his investment in transit costs. Goldberg told Kinzie "You are mersugar [sic] (crazy)! Green girls you can’t get here! A green girl is twice as much trouble as a wife... it's 100 per cent. better to get one who has done business on the other side." 83 If women had not previously practiced prostitution, the rarity of their status as green girls was heavily emphasized by both Kinzie and his informants, suggesting that few sex workers in the organized Jewish circuit were new to the field. ${ }^{84}$

Although many madams and brothel owners advised against taking the financial risk of recruiting "greenies," some pimps and traffickers pointed out and made use of the slipperiness of the slope between women's extramarital sexual activity and prostitution. They argued that women willing to have sex with multiple men for free could be easily enticed into prostitution -- "charity girls" (often referred to in more sexually explicit language), if willing to engage in a full menu of sexual acts, could be just as profitable and reliable as experienced sex workers. ${ }^{85}$ The two 
categories draw a bright line at virginity: green girls could be maidens, while charity girls are not. The distinction between women who have and have not been sexually active is a more important boundary than the exchange of money. As Goldberg explains to Kinzie: "“if a fellow loses his girl he goes to France or Russia and brings himself back a greeny (an inexperienced girl)'. I said 'Do you mean an absela (maiden)?'; he replied, 'No, a charity c---. This girl was a charity c---. He brought her here and when she got here she couldn't get work and neither could he; so, rather than starve to death she listened to reason." ${ }^{86}$ From the perspective of the men profiting from sex work, if women are willing to have sex at all, particularly with multiple partners, why would they do it for free if they could get paid for it? The pimps and brothel owners thus articulate women's sexuality as a commodity that can be improved under certain conditions, and would be irrational to give away for free.

As Kinzie sought to test the veracity of the victim narrative by seeking advice from brothel owners on how to best entrap a "fresh recruit," he was generally told that entrapment would not be worth the time, money, and effort, when plenty of women would not need to be fooled. When Kinzie insisted to a pimp, "I don't want any old stock," he was told, "fresh girls are too much trouble and pretty dangerous too." 87 Violent coercion, which was the usual explanation reformers used for their low success rates in saving women from white slavers, was particularly discouraged by Jewish sex work managers in Argentina: "That kind of a girl [green] is no good. I'll tell you why: ... You put her into a house and after a little while she packs up and runs away! This aint Russia, you know! You can't stop her! If you beat her you have a fine chance of getting into trouble!" 88 If an experienced woman would not do, love, rather than force, would be the optimal method.

In a parallel narrative to that of the standard white slave story, in which the handsome and wealthy stranger inveigles the naïve local girl into marriage, his advisors dissuaded the League investigator from his supposed quest for a novice, as an inefficient romantic seduction would be the only possible, profitable way. Goldberg warned him: "There is only one way, and that is to get a girl who likes you, and who will do as you say... [Green girls] fall only for love, and then it takes time to introduce them into our way of living, and to get them to bring in a dollar." 89 Managers described love as the only possible profitable way to recruit a virgin or other women not previously 
engaged in sex work. To encourage even experienced women to join forces with male managers in the dyadic structure that the marriage migration strategy required, attractive younger men played a critical role in the international network of sex importers. As one older trafficker articulated: "A young fellow can always get a girl to hustle the streets for him... The young girls don't want an alter cocher (old man). ${ }^{, 90}$ Police archival photographs of dozens of Ashkenazi Jewish men arrested as pimps in Buenos Aires in the 1890s capture many nattily dressed young men with carefully groomed hair and moustaches and elaborate ties and cravats, who can easily be pictured as seductive bait for young women seeking love marriages. ${ }^{91}$ While affective realities cannot be cleanly drawn from the archive, these voices suggest that emotional entanglements were among the many ties of these migratory networks.

The standard shtile khupe variation of the white slave narrative emphasized marriage as initial entrapment method, suggesting that these expedient unions would be dissolved after transport and deposit into brothels. Relationship patterns in local underworlds, however, indicate that marriage facilitated sex work well beyond recruitment and transit. Just as marriage proved to be a useful workaround for evading border restrictions, it also expanded work and life options on the ground, in the face of local regulations. A form of monogamy between working girls and pimps seems to have been enforced by both police and other members of the underworld. The dyadic unit would thus become strategically useful from the Old World, through the trans-Atlantic journey, and on into the Americas. ${ }^{92}$ The pragmatic goals of arranged marriage could be met in relationships between sex workers and others who both benefited from and facilitated their labor -- and at times the sentimental goals of the love match as well.

As in the transit phase of trafficking, marriage had multiple functions in the sex industry on the ground in Buenos Aires, which varied considerably from the published marriage ruse. Once on the ground, prostitutes' relationships with pimps are generally described by others in the business as relationships between "sweethearts." Kinzie encountered sex worker Fanny with her pimp Harry Kratzenbloom at Goldberg's boarding house when the "boss" wasn't home. ${ }^{93}$ The relationship dynamic described between this prostitute and her "sweetheart," despite Kinzie's quest for evidence of coercion, was one of a normal romantic relationship: the two invite Kinzie out for an afternoon walk; they stroll for a mile and enter a café, where the couple brainstorms

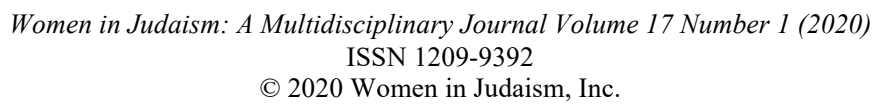


what to purchase as a present for her nephew in Warsaw, before finally deciding on a signet ring. ${ }^{94}$ Kinzie says he and the pimp then compared their signet rings. Fanny appeared content with a romantic partnership that could provide handsomely for her family back home. Kinzie appeared content with his signet ring and ability to connect with the pimp.

To summarize, the best way to make money in prostitution in this period, according to the Ashkenazi managers recorded in these sources, was to own properties conforming with brothel regulations; to use love rather than force get women to give you their best work and a share of their earnings; to allow women some say in relationship shifts between men; to refrain from mistreating women or forcing them to do what they don't want to; to maximize profits using stigmatized sexual practices; and to work as a collective group to invest in properties and bribe the police and other officials as needed. Familial relationships of blood and marriage as well as shared religion facilitated the trust that enabled sharing of resources and successful competition against less tightly-organized ethnic and national groups. Ties binding women in sex work to male managers were more likely to be affective than directly coercive. Sex workers as well as madams and brothel owners used marriage strategically. Women in Eastern Europe sometimes chose a quick religious marriage as an emigration strategy, even if aware that they might end up in prostitution. In some cases, they were already sex workers and were looking for a more lucrative market. Marriage helped single women and minors cross international borders, and continued to facilitate the business of sex on the ground. In the Varsovia Society, organized Ashkenazi Jews supported marriage and marriage-like relationships throughout the hierarchy of prostitutes, pimps, madams, doorkeepers, and property owners, and as a community supported a form of serial monogamy that looked more like the culture of more "respectable" Jews than like the non-Jewish circuits of commercial sex. While this structure maximized profit, it also created spaces for some women to make more extensive choices around work, love, and sexuality than might have otherwise have been available.

The trope of the rural virgin tricked into a sham marriage by a flashy seducer was as imprecise as the white slave narrative more broadly: entrapment occurred far less than constrained choice. The story was useful, however, for multiple groups. Concern about the lack of civil documentation of marriages meshed with state and religious authorities' desire for greater control

Women in Judaism: A Multidisciplinary Journal Volume 17 Number 1 (2020) 
over and information about individuals and families. Proposed solutions to the problem of the shtile khupe generally involved greater rabbinic and civil control over marriages, just as interwar governments sought increasing control over mobile populations. Fears about the shtile khupe underlined patriarchal reaction to the ascension of the love match: young people could not be trusted to make wise partner choices on their own, and rejecting parental authority would tear apart family and community structures as well as leave women vulnerable to exploitation and abandonment.

While migration and labor shifts certainly presented new risks for women, possibilities also opened to escape old problems. As evidenced in the transatlantic journeys excerpted above, some young women made choices to use marriage strategically for mobility, at times in consultation or collusion with family members. Many knew that new opportunities might include sex work. But given the limits of other possibilities, prostitution was not always as devastating a fate as reformers and other moralists feared. Although distinct from the shtile khupe trope, marriage was in fact a common element of the transnational movement of women for sex work, and prostitutes and managers often used marriage strategically. Because anti-trafficking laws assumed a dichotomy between wife and prostitute, between pimp and family man, marriage could serve as a cover for the movement of sex workers and help minors cross international borders. Marriage enabled evasion of border restriction, including policies intended to protect women from being trafficked. While authorities expressed great concern about the difference between civil and religious marriage, the legality of marriage mattered within the underworld predominantly to the extent that it could facilitate mobility across borders. Legal marriage was the exception rather than the rule, although many couples lived "as husband and wife." In practice, underworld members sought respectability on the same terms as mainstream society. ${ }^{95}$ In sum, marriage facilitated evasion of legal limitations, tightened organizational structure and services, facilitated business on the ground, and shaped the meaning underworld members made of their own lives.

According to the words of their managers and the few available from the women who worked in the brothels and other spaces of commercial sex in Buenos Aires, some chose to increase their life choices by marrying for purposes of transnational and economic mobility. Some remained in these or other relationships for business purposes or romantic connection. Life away from

Women in Judaism: A Multidisciplinary Journal Volume 17 Number 1 (2020) 
families of origin could permit new freedom of leisure, interaction, and sexual expression. Women's lives in sex work could also involve violence and coercion, but little evidence supports the extremes of white slave narratives. For both international anti-prostitution reformers and mainstream Jewish activists seeking to combat antisemitism and establish community respectability, the white slave victim narrative and marriage ruse story fit their goals better than the more ambiguous reality. Especially when comparing this nuanced model to antisemitic stereotypes, it is clear why the victim narrative of white slavery and quiet marriage was the one recirculated in popular culture, and that continues to resonate in anti-trafficking efforts to this day.

\section{Works Cited}

\section{Newspapers and Magazines}

\section{Buenos Aires Herald}

Di Prese [Buenos Aires, Argentina]

Los Angeles Times

McClure's Magazine

Orden [Santa Fe, Argentina]

\section{Archives}

Archives of Jewish Care, University of Southampton.

Papers of the Jewish Association for the Protection of Girls, Women and Children International Institute of Social History, Amsterdam.

Emma Goldman Papers

League of Nations Archive, Geneva.

$12 / 39498 / 28338$

Women in Judaism: A Multidisciplinary Journal Volume 17 Number 1 (2020) 
$12 / 58389 / 647$

$12 / 60144 / 647$

S148

S171

S180

Women's Library, London.

International Bureau for the Suppression of Traffic in Persons

\section{Published Primary Sources}

Asch, Sholem. “God of Vengeance.” In The Great Jewish Plays, translated by Joseph C Landis, 73-113. New York: Horizon Press, 1972.

Goldman, Emma. The White Slave Traffic. New York: Mother Earth Publishing Association, 1909.

Hippler, Fritz, dir. Der ewige Jude. Deutsche Filmherstellungs und Verwertungs, 1940. 62 min.

Jewish Association for the Protection of Girls and Women (JAPGW). Annual Report. London: JAPGW, 1932.

Jewish Association for the Protection of Girls and Women (JAPGW). Official Report of the Jewish International Conference on the Suppression of the Traffic in Girls and Women Held on April $5^{\text {th }}, 6^{\text {th }}$, and $7^{\text {th }}, 1910$, in London, Convened by the Jewish Association for the Protection of Girls and Women. London: JAPGW Central Bureau, 1910.

“Juzgados de instrucción: Número 3-Asociación ilicita." Gaceta de foro 15, no. 4729 (Nov. 1, 1930): 3-23.

Londres, Albert. Road to Buenos Ayres. New York: Boni and Liveright, 1928.

Women in Judaism: A Multidisciplinary Journal Volume 17 Number 1 (2020) 
Paleolog, Stanislawa. The Women Police of Poland (1925 to 1939). Translated by Eileen Garlinska. Westminster: Association for Moral and Social Hygiene, 1939.

Policía de la capital. Galería de sospechosos, vol. 1. Buenos Aires: Imprenta y encuadernación de la policía de la capital, 1894.

\section{Secondary Sources}

Agustín, Laura María. “Migrants in the Mistress's House: Other Voices in the 'Trafficking' Debate." Social Politics 12, no. 1 (Spring 2005): 96-117.

Agustín, Laura María. Sex at the Margins: Migration, Labour Markets, and the Rescue Industry. Zed Books, 2007.

Agustín, Laura María. “The Conundrum of Women's Agency: Migrations and the Sex Industry," In Sex Work Now, edited by M. O’Neill and R. Campbell, 116-140. Cullompton: Willan Publishing, 2006.

Agustín, Laura María. “The Cultural Study of Commercial Sex.” Sexualities 8, no. 5 (2005): $618-631$.

Agustín, Laura María. "The Disappearing of a Migration Category: Migrants Who Sell Sex." Journal of Ethnic and Migration Studies 32, no. 1 (Jan. 2006): 29-47.

Alpes, Maybritt Jill. "The Traffic in Voices: Contrasting the Experiences of Migrant Women in Prostitution with the Paradigm of "Human Trafficking." Human Security Journal 6 (Spring 2008), 34-45.

Andrijasevic, Rutvica. "Beautiful Dead Bodies: Gender, Migration, and Representation in Antitrafficking Campaigns.” Feminist Review 86, no. 1 (2007): 24-44.

Augustine-Adams, Kif. “'She Consents Implicitly’: Women’s Citizenship, Marriage, and Liberal Political Theory in Late-Nineteenth- and Early-Twentieth-Century Argentina." Journal of Women's History 13, no. 4 (Winter 2002): 8-30.

Barry, Kathleen. Female Sexual Slavery. New York: New York Univ. Press, 1979.

Bastia, Tanja. "Stolen Lives or Lack of Rights? Gender, Migration, and Trafficking." Labour, Capital, and Society 39, no. 2 (2006): 21-47.

Women in Judaism: A Multidisciplinary Journal Volume 17 Number 1 (2020) 
Ben, Pablo. "Plebeian Masculinity and Sexual Comedy in Buenos Aires, 1880-1930." Journal of the History of Sexuality 16, no. 3 (Sept. 2007): 436-458.

Bernstein, Elizabeth. "What's Wrong with Prostitution--What's Right with Sex Work-Comparing Markets in Female Sexual Labor.” Hastings Women's Law Journal 10, no. 1 (1999): 91-118.

Bristow, Edward J. Prostitution and Prejudice: The Jewish Fight against White Slavery, 18701939. 2nd ed. New York: Schocken Books, 1983.

Brodsky, Adriana M. Sephardi, Jewish, Argentine: Community and National Identity, 18801960. Bloomington: Indiana Univ. Press, 2016.

Casas, Laura Oso. "Money, Sex, Love, and the Family: Economic and Affective Strategies of Latin American Sex Workers in Spain.” Journal of Ethnic and Migration Studies 36, no. 1 (Jan. 2010): 47-65.

Chapkis, Wendy. Live Sex Acts: Women Performing Erotic Labor. New York: Routledge, 1997. Chaumont, Jean-Michel. Le mythe de la traite des blanches: Enquête sur la fabrication d'un fléau. Paris: La Découverte, 2009.

Choudhury, Shonali. “'As Prostitutes, We Control Our Bodies': Perceptions of Health and Body in the Lives of Establishment-based Female Sex Workers in Tijuana, Mexico." Culture, Health \& Sexuality 12, no. 6 (Aug. 2010): 677-689.

Connelly, Mark T. The Response to Prostitution in the Progressive Era. Chapel Hill: Univ. of North Carolina Press, 2011.

Devoto, Fernando. Historia de la inmigración en la Argentina. Buenos Aires: Editorial Sudamericana, 2003.

Dickenson, Donna. "Philosophical Assumptions and Presumptions about Trafficking for Prostitution." In Trafficking and Women's Rights, edited by Christien van den Anker and Jeroen Doomernik, 43-53. New York: Palgrave Macmillan, 2006.

Doezema, Jo. 'Ouch! Western Feminists' 'Wounded Attachment' to the 'Third World Prostitute."” Feminist Review, no. 67 (Winter 2001): 16-38.

Doezema, Jo. Sex Slaves and Discourse Masters: The Construction of Trafficking. New York: Palgrave Macmillan, 2010.

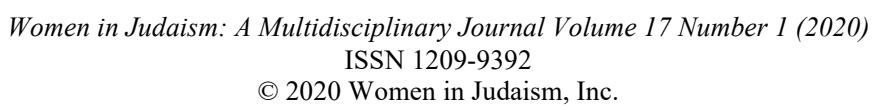


Donovan, Brian. White Slave Crusades: Race, Gender, and Anti-Vice Activism, 1887-1917. Champaign, IL: Univ. of Illinois Press, 2006.

Dubler, A. R. "Immoral Purposes: Marriage and the Genus of Illicit Sex." Yale Law Journal 115, no. 4 (January 2006): 756-812.

Echols, Alice. Daring To Be Bad: Radical Feminism in America 1967-1975. Minneapolis: Univ. of Minnesota Press, 1989.

Englander, David. "Stille-Huppah (Quiet Marriage) among Jewish Immigrants in Britain.” Jewish Journal of Sociology 34, no. 2 (December 1992): 85-109.

Feierstein, Ricardo. Historia de los judios argentinos. Buenos Aires: Editorial Galerna, 2006.

Feldman, Egal. "Prostitution, The Alien Woman And The Progressive Imagination, 1910-1915." American Quarterly 19, no. 2 (1967): 192-206.

Freeze, ChaeRan Y. Jewish Marriage and Divorce in Imperial Russia. Hanover: University Press of New England [for] Brandeis University Press, 2002.

Gayol, Sandra. Sociabilidad en Buenos Aires: Hombres, honor y cafés, 1862-1910. Buenos Aires: Ediciones del Siglo, 2000.

Gerhard, Jane. Desiring Revolution: Second-Wave Feminism and the Rewriting of American Sexual Thought, 1920 to 1982. New York: Columbia Univ. Press, 2001.

Glickman, Nora. The Jewish White Slave Trade and the Untold Story of Raquel Liberman. New York; London: Routledge, 1999.

Guereña, Jean-Luis. "El burdel como espacio de sociabilidad." Hispania: Revista española de historia 63, no. 214 (2003): 551-570.

Guy, Donna. Sex and Danger in Buenos Aires: Prostitution, Family, and Nation in Argentina. Lincoln: Univ. of Nebraska Press, 1991.

Howell, Philip. "Sex and the City of Bachelors: Sporting Guidebooks and Urban Knowledge in Nineteenth-Century Britain and America.” Ecumene 8, no. 1 (2001): 20-50.

Hua, Julietta. Trafficking Women's Human Rights. Minneapolis: University of Minnesota Press, 2011.

Jeffreys, Sheila. The Idea of Prostitution. Melbourne: Spinifex Press, 1997.

Women in Judaism: A Multidisciplinary Journal Volume 17 Number 1 (2020)
ISSN 1209-9392 
Jeffreys, Sheila. The Industrial Vagina: The Political Economy of the Global Sex Trade. New York: Taylor \& Francis, 2009.

Kempadoo, Kamala, and Jo Doezema, eds. Global Sex Workers. New York: Routledge, 1998. Kempadoo, Kamala, Jyoti Sanghera, and Bandana Pattanaik, eds. Trafficking and Prostitution Reconsidered: New Perspectives on Migration, Sex Work, and Human Rights. Boulder, CO: Paradigm Publishers, 2005.

Levine, Philippa. Prostitution, Race and Politics: Policing Venereal Disease in the British Empire. New York: Routledge, 2003.

Lewin, Boleslao. Cómo fue la inmigración judía a la Argentina. Buenos Aires: Plus Ultra, 1983. Liempt, Ilse C. van. “Trafficking in Human Beings: Conceptual Dilemmas.” In Trafficking and Women's Rights, 27-42. Houndsmills: Palgrave Macmillan, 2006.

MacKinnon, Catharine. Toward a Feminist Theory of the State. Cambridge, MA: Harvard Univ. Press, 1989.

Magar, Veronica. 'Rescue and Rehabilitation: A Critical Analysis of Sex Workers' Antitrafficking Response in India.” Signs 37, no. 3 (March 2012): 619-644.

Manalansan, M. F. “Queer Intersections: Sexuality and Gender in Migration Studies.”

International Migration Review 40, no. 1 (Spring 2006): 224-249.

Mays, Devi. "Transplanting Cosmopolitans: The Migrations of Sephardic Jews to Mexico, 19001934.” PhD diss., Indiana Univ., 2013.

McDonald, William. "Traffic Counts, Symbols, and Agendas: A Critique of the Campaign Against Trafficking of Human Beings.” International Review of Victimology 11 (2004): $143-176$.

McLaughlin, L. "Discourses of Prostitution Discourses of Sexuality." Critical Studies in Mass Communication 8, no. 3 (Sept. 1991): 249-272.

Mirelman, Victor A. Jewish Buenos Aires, 1890-1930: In Search of an Identity. Detroit: Wayne State Univ. Press, 1990.

Pedersen, Susan. The Guardians: The League of Nations and the Crisis of Empire. New York: Oxford Univ. Press, 2015.

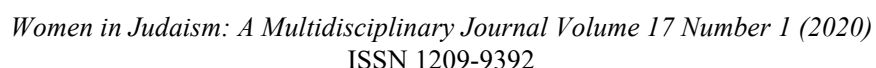
(C) 2020 Women in Judaism, Inc.

All material in the journal is subject to copyright; copyright is held by the journal except where otherwise indicated. There is to be no reproduction or distribution of contents by any means without prior permission. Contents do not necessarily reflect the views of the editors. 
Pivar, David. Purity and Hygiene: Women, Prostitution, and the 'American Plan,' 1900-1930.

Westport, Conn.: Greenwood Press, 2002.

Romagnolli, G. Aspectos jurídicos e institucionales de las migraciones en la república argentina. Geneva: OIM, 1991.

Rosenswaike, Ira. "The Jewish Population of Argentina: Census and Estimate, 1887-1947." Jewish Social Studies 22, no. 4 (Oct. 1960): 195-214.

Sandell, Marie. The Rise of Women's Transnational Activism: Identity and Sisterhood between the World Wars. New York: I.B. Tauris, 2015.

Seidman, Naomi. The Marriage Plot: Or, How Jews Fell in Love with Love, and with Literature. Stanford: Stanford Univ. Press, 2016.

Soderlund. Gretchen. 'Covering Urban Vice: The New York Times, 'White Slavery,' and the Construction of Journalistic Knowledge.” Critical Studies in Media Communication no. 4 (2002): 438-460.

Soderlund. Gretchen. Sex Trafficking, Scandal, and the Transformation of Journalism, 18851917. Chicago: Univ. of Chicago, 2013.

Stauter-Halsted, Keely. The Devil's Chain: Prostitution and Social Control in Partitioned Poland. Ithaca: Cornell Univ. Press, 2015.

Van Onselen, Charles. "Jewish Marginality in the Atlantic World: Organized Crime in the Era of the Great Migrations, 1880-1914.” South African Historical Journal, no. 43 (2000): 96137.

Van Onselen, Charles. "Jewish Police Informers in the Atlantic World, 1880-1914.” Historical Journal 50, no. 1 (March 2007): 119-144.

Van Onselen, Charles. The Fox and the Flies: The Secret Life of a Grotesque Master Criminal. New York: Walker \& Company, 2007.

Walkowitz, Judith R. Prostitution and Victorian Society: Women, Class, and the State. New York: Cambridge Univ. Press, 1982.

Weitzer, Ronald. "Flawed Theory and Method in Studies of Prostitution." Violence Against Women 11 (2005): 934-949.

\footnotetext{
Women in Judaism: A Multidisciplinary Journal Volume 17 Number 1 (2020) ISSN 1209-9392 (C) 2020 Women in Judaism, Inc.
} 
Yarfitz, Mir. Impure Migration: Jews and Sex Work in Golden Age Argentina. New Brunswick, NJ: Rutgers Univ. Press, 2019.

Yarfitz, Mir. "Uprooting the Seeds of Evil: Ezras Noschim and Jewish Marriage Regulation, Morality Certificates, and Degenerate Prostitute Mothers in 1930s Buenos Aires.” In The New Jewish Argentina: Facets of Jewish Experiences in the Southern Cone, edited by Adriana Brodsky and Raanan Rein, 55-80. Leiden: Brill, 2012. Yea, Sallie. “'Shades of Grey’: Spaces in and beyond Trafficking for Thai Women Involved in Commercial Sexual Labour in Sydney and Singapore." Gender, Place \& Culture: A Journal of Feminist Geography 19, no 1 (2012): 42-60.

\footnotetext{
1 "La Sociedad Varsovia vista por dentro segun el relato de uno de sus socios," Orden, May 30, 1930. Translation is mine, as are all others from Spanish. Translations from Yiddish by myself and Will Runyan. Thanks to Jeffrey Shandler and Marcy Brink-Danan for their multiple rounds of feedback on this project, and to Kirsten Fermaglich, Adam Mendelsohn, and Daniel Soyer for their input on an earlier version of this essay. Any mistakes or oversights are my responsibility.

2 This project uses the term "white slave" to discuss this narrative trope, without sharing the assumption (generally continued through its replacement term "trafficking") that the experiences referenced were always entirely coercive. The terms "sex worker" and "sex work" will generally be used instead of "prostitute" and "prostitution," and the term "sex work manager" in place of pimp, madam, or trafficker. While the agency implied in "sex work" fits better with this project's overall argument, it is also a historically anachronistic term, not created until the 1970s.

${ }^{3}$ See, for example: Gretchen Soderlund, Sex Trafficking, Scandal, and the Transformation of Journalism, $1885-1917$ (Chicago: Univ. of Chicago, 2013); Brian Donovan, White Slave Crusades: Race, Gender, and Anti-Vice Activism, 1887-1917 (Champaign, IL: Univ. of Illinois Press, 2006); Marie Sandell, The Rise of Women's Transnational Activism: Identity and Sisterhood between the World Wars (New York: I.B. Tauris, 2015).

${ }^{4}$ In the book which launched the historical study of prostitution in Argentina and in Latin America more generally, and continues to be a critical reference, Donna Guy overviews the evolution of the Argentine system regulating sex work in Sex and Danger in Buenos Aires: Prostitution, Family, and Nation in Argentina (Lincoln: Univ. of Nebraska Press, 1991).

${ }^{5}$ Nazi claim made in Fritz Hippler, dir., Der ewige Jude (Deutsche Filmherstellungs und Verwertungs, 1940), 62 $\min$.

${ }^{6}$ For historical analysis of the international Jewish role in this era's sex trade, see Charles Van Onselen, "Jewish Marginality in the Atlantic World: Organized Crime in the Era of the Great Migrations, 1880-1914," South African Historical Journal, no. 43 (2000): 96-137, “Jewish Police Informers in the Atlantic World, 1880-1914," Historical Journal 50, no. 1 (March 2007): 119-144, and The Fox and the Flies: The Secret Life of a Grotesque Master Criminal (New York: Walker \& Company, 2007); Edward J. Bristow, Prostitution and Prejudice: The Jewish Fight against White Slavery, 1870-1939, 2nd ed. (New York: Schocken Books, 1983); Mir Yarfitz, Impure Migration: Jews and Sex Work in Golden Age Argentina (New Brunswick, NJ: Rutgers University Press, 2019).

${ }^{7}$ On male sociability in this context see Jean-Luis Guereña, "El burdel como espacio de sociabilidad," Hispania: Revista española de historia 63, no. 214 (2003): 551-570 and Philip Howell, "Sex and the City of Bachelors: Sporting Guidebooks and Urban Knowledge in Nineteenth-Century Britain and America," Ecumene 8, no. 1 (2001): 20-50. For more on Buenos Aires male sociability see Pablo Ben, "Plebeian Masculinity and Sexual Comedy in
}

Women in Judaism: A Multidisciplinary Journal Volume 17 Number 1 (2020) 
Buenos Aires, 1880-1930," Journal of the History of Sexuality 16, no. 3 (Sept. 2007): 436-458; and Sandra Gayol, Sociabilidad en Buenos Aires: Hombres, honor y cafés, 1862-1910 (Buenos Aires: Ediciones del Siglo, 2000). ${ }^{8}$ For narrative ease, I refer to the Jewish community as a whole, but I do not intend to flatten the diversity of Jewish experience in Argentina, particularly the differences between Sephardi and Ashkenazi Jewish life in this period. On the contours of Sephardi vs. Ashkenazi Argentine-Jewish identity, see the field-defining work of Adriana M. Brodsky, particularly her comprehensive Sephardi, Jewish, Argentine: Community and National Identity, 1880-1960 (Bloomington: Indiana Univ. Press, 2016).

${ }^{9}$ Estimating the numbers of Jews historically resident in Argentina has been a matter of debate among historians, in large part because the country had only two national censuses in the main period of Jewish population growth (1900 to 1960), in 1914 and 1947, and only the latter enquired about religion, although many of those surveyed did not declare one. Ira Rosenswaike, "The Jewish Population of Argentina: Census and Estimate, 1887-1947," Jewish Social Studies 22, no. 4 (October 1960): 196; Ricardo Feierstein, Historia de los judios argentinos (Buenos Aires: Editorial Galerna, 2006), 136-137. The city of Buenos Aires, where the great majority of the country's Jews lived, took censuses in 1904, 1909, and 1936, of which the last was the most detailed. Rosenswaike, "The Jewish Population of Argentina," 196. I analyze the data on registered Jewish prostitutes in Chapter Two of Impure Migrations, in which 1899-1915 raw numbers come from citation of Carlos Bernaldo de Quiros, 208 in Boleslao Lewin, Cómo fue la inmigración iudía a la Argentina (Buenos Aires: Plus Ultra, 1983) and 1910-1923 numbers from Victor A. Mirelman, Jewish Buenos Aires, 1890-1930: In Search of an Identity (Detroit: Wayne State University Press, 1990), 205, from Records of Buenos Aires Municipal Health Department. I correlated these with an identical version of this data from June 16, 1924, in the League of Nations archive, S171. For January to May 1924, my calculations come from the reply to League of Nations questionaire sent by Jacinto Fernandez, Buenos Aires Police, July 30, 1924, p. 6, 12/39498/28338, League of Nations Archive, Geneva.

${ }^{10}$ Rosenswaike, "The Jewish Population of Argentina," 197. For these arrest records, see Policía de la capital, Galería de sospechosos, vol. 1 (Buenos Aires: Imprenta y encuadernación de la policía de la capital, 1894), further analyzed along with these census data in Yarfitz, Impure Migrations.

${ }^{11}$ The Society was originally called Varsovia, Spanish for Warsaw, and changed its name in 1927 to Zwi Migdal, in honor of founding president Luis Migdal. In an effort to reduce the confusion of two names, it will generally be referred to as the Varsovia Society. For more on the organization's structure and development, see Yarfitz, Impure Migrations.

${ }^{12}$ For more on this court case and the evolution of sex work regulation in Argentina, see Yarfitz, Impure Migrations, Introduction and Chapter Five, and Guy, Sex and Danger. On the release of imprisoned members, see "Not Proven: Zwi Migdal Members Released," Buenos Aires Herald (Jan. 28, 1931). Argentine consuls in Europe were notified that all these deportees were deprived of their Argentine citizenship, and should not be given visas to return to Argentina. Letter from R. Lighton Robinson to Sempkins, \#83 of Feb. 12, 1931, London, Women's Library, International Bureau for the Suppression of Traffic in Persons, 4IBS/6, FL112, folder 1J - Argentine - Zwii Mygdal case [sic].

${ }^{13}$ Neither the name Arnold nor any similar surname paired with a last name beginning with $\mathrm{K}$ appears in the arrest records or other archival documents associated with the 1930 arrests. This suggests that this name was an alias, that he was not actually a Society member, or that these records were incomplete. The reporter in this newspaper series dramatically accuses Arnold K. of having applied to the Varsovia Society for membership and been rejected, which provides another explanation.

${ }^{14}$ In her excellent analysis of the history of sex work in Poland, Keely Stauter-Halsted calls for further historical investigation of the links between ritual marriage and Jewish involvement in sex trafficking, pointing out the internal and external limitations of existing scholarship, some of which this essay attempts to overcome. Stauter-Halsted, The Devil's Chain: Prostitution and Social Control in Partitioned Poland (Ithaca: Cornell Univ. Press, 2015), 184. 15 "A vendung... Rodriguez Ocampo," Di Prese, May 23, 1930.

16 "Wiles of the White Slaver: Charitable Institution as 'Exchange," Buenos Aires Herald, May 11, 1930.

${ }^{17}$ Albert Londres, Road to Buenos Ayres (New York: Boni and Liveright, 1928), 171. French edition published in 1927.

${ }^{18}$ George Kibbe Turner, "The City of Chicago: A Study of the Great Immoralities," McClure's Magazine 28:6 (April 1907): 575; George Kibbe Turner, “Tammany's Control of New York by Professional Criminals," McClure's Magazine 33:2 (June 1909): 117; George Kibbe Turner, "The Daughters of the Poor: A Plain Story of the 30 Women in Judaism: A Multidisciplinary Journal Volume 17 Number 1 (2020) ISSN 1209-9392

(C) 2020 Women in Judaism, Inc.

All material in the journal is subject to copyright; copyright is held by the journal except where otherwise indicated. There is to be no reproduction or distribution of contents by any means without prior permission. Contents do not necessarily reflect the views of the editors. 
Development of New York City as a Leading Center of the White Slave Trade of the World, Under Tammany Hall," McClure's Magazine 34:1 (November 1909): 45.

${ }^{19}$ Quoted in Egal Feldman, "Prostitution, The Alien Woman and The Progressive Imagination, 1910-1915," American Quarterly 19, no. 2 (1967): 197.

20 "Jewish Girls are Sacrificed: Sensational Disclosures in Chicago Ghetto," Los Angeles Times, October 21, 1907.

${ }^{21}$ Cited in Feldman, "Prostitution, The Alien Woman and The Progressive Imagination," 196.

${ }^{22}$ Bristow, Prostitution and Prejudice, 102-108.

${ }^{23}$ See for example: David Englander, "Stille-Huppah (Quiet Marriage) among Jewish Immigrants in Britain," Jewish Journal of Sociology 34, no. 2 (December 1992): 93; David Pivar, Purity and Hygiene: Women, Prostitution, and the 'American Plan,' 1900-1930 (Westport, Conn.: Greenwood Press, 2002), 90n75.

${ }^{24}$ Stauter-Halsted, Devil's Chain, 184.

${ }^{25}$ On changes in Jewish marriage in a broader context, see Naomi Seidman, The Marriage Plot: Or, How Jews Fell in Love with Love, and with Literature (Stanford: Stanford Univ. Press, 2016); ChaeRan Y. Freeze, Jewish Marriage and Divorce in Imperial Russia (Hanover: University Press of New England [for] Brandeis University Press, 2002). On women's rights and marriage in Argentina in the period, see Kif Augustine-Adams, "'She Consents Implicitly': Women's Citizenship, Marriage, and Liberal Political Theory in Late-Nineteenth- and Early-Twentieth-Century Argentina," Journal of Women's History 13, no. 4 (Win 2002): 8-30.

${ }^{26}$ Jewish Association for the Protection of Girls and Women (JAPGW), Official Report of the Jewish International Conference on the Suppression of the Traffic in Girls and Women Held on April $5^{\text {th }}, 6^{\text {th }}$, and $7^{\text {th }}, 1910$, in London, Convened by the Jewish Association for the Protection of Girls and Women (London: JAPGW Central Bureau, 1910), 109-110.

27 “'Ezras Noschim' un 'imigrantn-shutz farain' rufn a delegatn farzamlung,” Di Prese, June 16, 1930.

${ }^{28}$ Stauter-Halsted, Devil's Chain, 182.

${ }^{29}$ Freeze, Jewish Marriage and Divorce in Imperial Russia, 97-98.

${ }^{30}$ Stauter-Halsted, Devil's Chain, 183.

31 "Jewish Ritual Weddings" section of "Memorandum and Proposals of the Polish National Committee for the Suppression of Traffic in Woman and Children [sic] submitted to the VII International Congress on the Subject of the Suppression of Traffic in Women," June 1927, 12/58389/647, League of Nations Archive, Geneva, 6-8.

32 Jews continued to be blamed for the origination of prostitution in Poland and its international aspect in the 1939 Polish policewoman's memoir Stanislawa Paleolog, The Women Police of Poland (1925 to 1939), translated by Eileen Garlinska (Westminster: Association for Moral and Social Hygiene, 1939), e.g., 4.

33 "Jewish Ritual Weddings," 6-8.

34 "Big Percentage of Jewish Prostitution in Poland: The Effect of the Immigration Quota Restrictions," in Jewish Telegraphic Association section of conference notes for VII International Congress on the Subject of the Suppression of Traffic in Women, June 24, 1927, 12/60144/647, League of Nations Archive, Geneva, 3.

35 "Big Percentage of Jewish Prostitution," 2.

36 "Big Percentage of Jewish Prostitution," 2.

37 "Big Percentage of Jewish Prostitution," 2.

${ }^{38}$ Handwritten notes from Argentine investigation, June 1-15, 1924, Field Reports on Investigation of International Traffic in Women and Children Made for the Special Body of Experts to Study The International Traffic in Women and Children, S171, League of Nations Archive, Geneva, 1.

39 JAPGW, Annual Report (London: JAPGW, 1932), 31.

${ }^{40}$ Mir Yarfitz, "Uprooting the Seeds of Evil: Ezras Noschim and Jewish Marriage Regulation, Morality Certificates, and Degenerate Prostitute Mothers in 1930s Buenos Aires," pp. 55-80 in The New Jewish Argentina: Facets of Jewish Experiences in the Southern Cone, edited by Adriana Brodsky and Raanan Rein (Leiden: Brill, 2012).

${ }^{41}$ Fernando Devoto, Historia de la inmigración en la Argentina (Buenos Aires: Editorial Sudamericana, 2003), 361. 42 "Algiers, Algeria: Traffic in Women and Children," February 14-16, 1925, Field Reports on Investigation of International Traffic in Women and Children Made for the Special Body of Experts to Study The International Traffic in Women and Children, S148, League of Nations Archive, Geneva, 9.

43 "Marseilles, France: Traffic in Women and Children," January 1-5, 1925, Field Reports on Investigation of International Traffic in Women and Children Made for the Special Body of Experts to Study The International Traffic in Women and Children, S148, League of Nations Archive, Geneva, 7. ISSN 1209-9392

(C) 2020 Women in Judaism, Inc.

All material in the journal is subject to copyright; copyright is held by the journal except where otherwise indicated. There is to be no reproduction or distribution of contents by any means without prior permission. Contents do not necessarily reflect the views of the editors. 
44 "Marseilles, France: Traffic in Women and Children," 14.

45 "Genoa, Italy: Traffic in Women and Children," March 5-10, 1925, Field Reports on Investigation of International Traffic in Women and Children Made for the Special Body of Experts to Study The International Traffic in Women and Children, S148, League of Nations Archive, Geneva, 5-8.

46 "Juzgados de instrucción: Número 3-Asociación ilicita," Gaceta de foro 15, no. 4729 (Nov. 1, 1930): 3-23; Rio de Janeiro Field Reports, Field Reports on Investigation of International Traffic in Women and Children Made for the Special Body of Experts to Study The International Traffic in Women and Children, S148, League of Nations Archive, Geneva, 37. Henceforth Rio Field Reports. The creation and control of the passport system in this period, particularly after World War I, was a new articulation of nationality which both facilitated and restricted movement. Many migrants challenged government efforts to limit their national identification and mobility by altering and falsifying passports and other documentation both during and after migratory processes. See Devi Mays,

"Transplanting Cosmopolitans: The Migrations of Sephardic Jews to Mexico, 1900-1934" (PhD diss., Indiana Univ., 2013), 38-41.

47 "Marseilles, France: Traffic in Women and Children," 12-14.

48 "Marseilles, France: Traffic in Women and Children," 13.

${ }^{49}$ December 311923 law 817 restricting immigration discussed in G. Romagnolli, Aspectos jurídicos e institucionales de las migraciones en la república argentina (Geneva: OIM, 1991): 15-17; Devoto, Historia de la inmigración, 360-61.

${ }^{50}$ For example, "Iz der froien-handl nar fun oisland?" Di Prese, October 7, 1930.

${ }^{51}$ For example, in Genoa, a sex worker describes the process of quitting a registered house, thus getting out of the system, and then getting a passport with no record they had ever been registered. "Genoa, Italy: Traffic in Women and Children," 5.

52 "Exhibit M: Uruguay," Questionnaire C.L. 61, 1924, Commission of Experts, Traffic in Women and Children, S180, League of Nations Archive, Geneva, 1.

${ }^{53}$ Romagnolli, Aspectos jurídicos e institucionales, 15-17; "Marseilles, France: Traffic in Women and Children," 79.

54 "La Sociedad Varsovia vista por dentro," 3.

${ }^{55}$ Philippa Levine, Prostitution, Race and Politics: Policing Venereal Disease in the British Empire (New York: Routledge, 2003); Judith R. Walkowitz, Prostitution and Victorian Society: Women, Class, and the State (New York: Cambridge Univ. Press, 1982). In 1900, the Jewish reformers in Britain working to found the JAPGW used the Contagious Disease Acts as shorthand for the entire concept of the regulatory system, noting that the "Contagious Diseases Acts [were] in force in the Argentine Republic." Minutes and Papers of the Gentlemen's SubCommittee for Preventative Work, 188-89, Papers of the Jewish Association for the Protection of Girls, Women and Children, Archives of Jewish Care, University of Southampton.

${ }^{56}$ Kathleen Barry's most influential work on this subject is Female Sexual Slavery (New York: New York Univ. Press, 1979). For a critique of Barry's position and the CATW, see, e.g., Jo Doezema, "Ouch! Western Feminists' 'Wounded Attachment' to the 'Third World Prostitute," Feminist Review, no. 67 (Win 2001): 16-38. Other key works articulating this position include Catharine MacKinnon, Toward a Feminist Theory of the State (Cambridge, MA: Harvard Univ. Press, 1989) and Sheila Jeffreys, The Idea of Prostitution (Melbourne: Spinifex Press, 1997), rearticulated as a global phenomenon in Jeffreys's The Industrial Vagina: The Political Economy of the Global Sex Trade (New York: Taylor \& Francis, 2009).

${ }^{57}$ Jo Doezema's scholarship highlights the parallels between today's anti-human and sex trafficking activism and the images invoked in the historical "myth of white slavery." Jo Doezema, Sex Slaves and Discourse Masters: The Construction of Trafficking (New York: Palgrave Macmillan, 2010). In 2009, Women's Studies International Forum hosted a debate between the radical feminist and sex work responses to trafficking, vol. 32, no. 4.

${ }^{58}$ Gerhard, Desiring Revolution, 149-196. On the feminist "sex wars," see the epilogue to Alice Echols, Daring To Be Bad: Radical Feminism in America 1967-1975 (Minneapolis: Univ. of Minnesota Press, 1989), 287-298 and Jane Gerhard, Desiring Revolution: Second-Wave Feminism and the Rewriting of American Sexual Thought, 1920 to 1982 (New York: Columbia Univ. Press, 2001).

${ }^{59}$ See Emma Goldman, The White Slave Traffic (New York: Mother Earth Publishing Association, 1909); revised into "The Traffic in Women." In a draft of this article, she argued with George Kibbe Turner against the accusations of Jewish dominance of the Chicago traffic as Jewish women could not have been attractive or acculturated enough 2 Women in Judaism: A Multidisciplinary Journal Volume 17 Number 1 (2020) ISSN 1209-9392

(C) 2020 Women in Judaism, Inc.

All material in the journal is subject to copyright; copyright is held by the journal except where otherwise indicated. There is to be no reproduction or distribution of contents by any means without prior permission. Contents do not necessarily reflect the views of the editors. 
Emma Goldman, “The White Slave Traffic,” Emma Goldman Papers, International Institute of Social History, Amsterdam, 6-7.

${ }^{60}$ Much has been written on the language of sex work and this feminist position; see, for example: Elizabeth Bernstein, "What's Wrong with Prostitution-What's Right with Sex Work-Comparing Markets in Female Sexual Labor," Hastings Women's Law Journal 10 (1999): 91-118; Kamala Kempadoo and Jo Doezema, eds., Global Sex Workers (New York: Routledge, 1998); L. McLaughlin, "Discourses of Prostitution Discourses of Sexuality," Critical Studies in Mass Communication 8, no. 3 (September 1991): 249-272; Shonali Choudhury, “As Prostitutes, We Control Our Bodies': Perceptions of Health and Body in the Lives of Establishment-based Female Sex Workers in Tijuana, Mexico," Culture, Health \& Sexuality 12, no. 6 (Aug. 2010): 677-689.

${ }^{61}$ Nearly all of the forty panelists shared this position at the Conference on Trafficking, Smuggling, and Illicit Migration in Historical Perspective at University of London, Birkbeck, June 18-20, 2015. Laura María Agustín has been one of the most influential scholars to interpret trafficking in a migratory framework; see her Sex at the Margins: Migration, Labour Markets, and the Rescue Industry (Zed Books, 2007); “The Conundrum of Women's Agency: Migrations and the Sex Industry," in Sex Work Now, edited by M. O'Neill and R. Campbell (Cullompton: Willan Publishing, 2006), 116-140; "The Disappearing of a Migration Category: Migrants Who Sell Sex," Journal of Ethnic and Migration Studies 32, no. 1 (Jan. 2006): 29-47; "The Cultural Study of Commercial Sex," Sexualities 8, no. 5 (2005): 618-631; and "Migrants in the Mistress's House: Other Voices in the 'Trafficking' Debate," Social Politics 12, no. 1 (Spring 2005): 96-117. On the migration connection, see also: Sallie Yea, “'Shades of Grey': Spaces in and beyond Trafficking for Thai Women Involved in Commercial Sexual Labour in Sydney and Singapore," Gender, Place \& Culture: A Journal of Feminist Geography 19, no 1 (2012): 42-60; Veronica Magar, "Rescue and Rehabilitation: A Critical Analysis of Sex Workers' Antitrafficking Response in India," Signs 37, no. 3 (March 1, 2012): 619-644; Rutvica Andrijasevic, "Beautiful Dead Bodies: Gender, Migration, and Representation in Anti-trafficking Campaigns," Feminist Review 86, no. 1 (2007): 24-44; M. F. Manalansan, "Queer Intersections: Sexuality and Gender in Migration Studies," International Migration Review 40, no. 1 (Spring 2006): 224-249; Tanja Bastia, "Stolen Lives or Lack of Rights? Gender, Migration, and Trafficking," Labour, Capital, and Society 39, no. 2 (2006): 21-47; Kamala Kempadoo, Jyoti Sanghera, and Bandana Pattanaik, eds., Trafficking and Prostitution Reconsidered: New Perspectives on Migration, Sex Work, and Human Rights (Boulder, CO: Paradigm Publishers, 2005); Laura Oso Casas, "Money, Sex, Love, and the Family: Economic and Affective Strategies of Latin American Sex Workers in Spain," Journal of Ethnic and Migration Studies 36, no. 1 (Jan. 2010): 47-65. Julietta Hua provides a thought-provoking critique of human rights discourse around trafficking in Trafficking Women's Human Rights (Minneapolis: University of Minnesota Press, 2011).

${ }^{62}$ Maybritt Jill Alpes, "The Traffic in Voices: Contrasting the Experiences of Migrant Women in Prostitution with the Paradigm of 'Human Trafficking'," Human Security Journal 6 (Spring 2008), 34-45; 37.

${ }^{63}$ While not all sex workers are women, feminist analyses are generally based on the norm of male clients and female sellers of sex. Trans women in sex work are at even greater risk of violence from clients and the state, and face more limited choices than other women. For an example of the modified choice argument, see Wendy Chapkis, Live Sex Acts: Women Performing Erotic Labor (New York: Routledge, 1997). On consent see also Ilse C. van Liempt, "Trafficking in Human Beings: Conceptual Dilemmas," 27-42 in Trafficking and Women's Rights (Houndsmills: Palgrave Macmillan, 2006) and Donna Dickenson, "Philosophical Assumptions and Presumptions about Trafficking for Prostitution," 43-53 in Christien van den Anker and Jeroen Doomernik, eds., Trafficking and Women's Rights (New York: Palgrave Macmillan, 2006). Doezema critiques this model in Sex Slaves and Discourse Masters, 24-25.

${ }^{64}$ Quoted in Nora Glickman, The Jewish White Slave Trade and the Untold Story of Raquel Liberman (New York; London: Routledge, 1999), 38, from Szichman's novel A las 20:25 la señora entró en la inmortalidad (1981).

${ }^{65}$ Jo Doezema pushes further in granting agency to historical and present-day sex workers, suggesting that women's desires for various forms of freedom might make sex work less oppressive than other employment options. Sex workers might have more room to shape their working conditions than restaurant servers, into whose work sexuality enters implicitly but its terms cannot be directly negotiated. Doezema, Sex Slaves and Discourse Masters, 12. ${ }^{66}$ The recent surge of interest in the League of Nations is epitomized by Susan Pedersen, The Guardians: The League of Nations and the Crisis of Empire (New York: Oxford Univ. Press, 2015). Work in French also engages deeply with the archives of the League's Traffic in Women Committee, e.g., Jean-Michel Chaumont, Le mythe de la traite des blanches: Enquête sur la fabrication d'un fléau (Paris: La Découverte, 2009). ISSN 1209-9392

(C) 2020 Women in Judaism, Inc.

All material in the journal is subject to copyright; copyright is held by the journal except where otherwise indicated. There is to be no reproduction or distribution of contents by any means without prior permission. Contents do not necessarily reflect the views of the editors. 
${ }^{67}$ Gaceta de foro, 3-23.

68 "Prostitutes Alleged to be Under 21 Years of Age," 22 July 1924, Rio Field Reports.

69 "Traffic in Women and Children: Summary," 25 May - 14 June, 1924, Buenos Aires Field Reports, Field Reports on Investigation of International Traffic in Women and Children Made for the Special Body of Experts to Study The International Traffic in Women and Children, S148, League of Nations Archive, Geneva. Henceforth Buenos Aires Field Reports.

${ }^{70}$ In one of many examples in which women moved in and out of prostitution over their lives, Ike Rosen described bringing Dolly or Dottie from Warsaw, where she engaged in some sex work but not extensively, as well as while passing through Paris and London: "She did a little, but not much." Rio Field Reports, 22. Names and nicknames, as opposed to codes such as 48T for a particular trafficker, were found in the "Codebook [to code used in Field Reports]," Field Reports on Investigation of International Traffic in Women and Children Made for the Special Body of Experts to Study The International Traffic in Women and Children, S171, League of Nations Archive, Geneva. Henceforth Codebook.

71 "Investigation on the Spot for the Commission of Experts Appointed by the Council of the League of Nations to Study, in Collaboration with Governments, the Conditions under which the Traffic in Women and Children is Carried on," Buenos Aires Field Reports, 11.

${ }^{72}$ See "Classification of Houses," Rio Field Reports, 2, for an example of a previously practicing sex worker who said she came from Warsaw to Rio to make more money, though the investigator is suspicious of her age and story.

${ }^{73}$ Buenos Aires Field Reports, 11.

${ }^{74}$ Sholem Asch, "God of Vengeance," in The Great Jewish Plays, trans. Joseph C Landis (New York: Horizon Press, 1972), 73-113.

75 "Police Raids a 'Wash-Out': Only Ten White Slavers Caught," Buenos Aires Herald, May 23, 1930.

${ }^{76}$ Gaceta de foro.

${ }^{77}$ Buenos Aires Field Reports, 38.

${ }^{78}$ Gaceta de foro, 3-23.

${ }^{79}$ E.g., Buenos Aires Field Reports, 16-17.

${ }^{80}$ Stauter-Halsted, Devil's Chain, 185-188.

${ }^{81}$ Gretchen Soderlund examines how the New York Times approached this subject in the 1910s in "Covering Urban Vice: The New York Times, 'White Slavery,' and the Construction of Journalistic Knowledge," Critical Studies in Media Communication no. 4 (2002): 438-460. Donna Guy in Sex and Danger shows how the statistics from Argentine municipal prostitutes' health registries were used as evidence for not just the existence of sex work, but for the idea that regulation promoted coercive international trafficking. Mark Connelly assesses the sensationalistic misrepresentation of evidence presented by the 1911 Chicago Vice Commission in subsequent white slavery narratives. Mark T. Connelly, The Response to Prostitution in the Progressive Era (Chapel Hill: Univ. of North Carolina Press, 2011). See also Ronald Weitzer, "Flawed Theory and Method in Studies of Prostitution," Violence Against Women 11 (2005): 934-949 and William McDonald, "Traffic Counts, Symbols, and Agendas: A Critique of the Campaign Against Trafficking of Human Beings," International Review of Victimology 11 (2004): 143-176.

82 "Exhibit M: Uruguay," 1.

${ }^{83}$ Buenos Aires Field Reports, 39, 49.

${ }^{84}$ E.g. discussion of green girl from Warsaw, Buenos Aires Field Reports, 44-45.

85 "Marseilles, France: Traffic in Women and Children," 13-14. On marriage as intertwined with the history of the boundaries of licit vs illicit sex, see A. R. Dubler, "Immoral Purposes: Marriage and the Genus of Illicit Sex," Yale Law Journal 115, no. 4 (January 2006): 756-812.

${ }^{86}$ Buenos Aires Field Reports, 17. Absela is probably a corruption of bsule, virgin, from a bsile, a virgin, in the Polish dialect of Yiddish.

87 "Constantinople, Turkey: Traffic in Women and Children," 7.

${ }^{88}$ Buenos Aires Field Reports, 40.

${ }^{89}$ Buenos Aires Field Reports, 40.

${ }^{90}$ Buenos Aires Field Reports, 46. Yiddish term alter kokher literally means "old shitter."

${ }^{91}$ Policía de la capital, Galería de sospechosos.

92 "Marseilles, France: Traffic in Women and Children," 7, 12-14.

${ }^{93}$ Names decoded in Codebook. 
${ }^{94}$ Buenos Aires Field Reports, 44-45.

${ }^{95}$ For more on the Varsovia Society's efforts to engage normative standards of respectability, see Yarfitz, Impure Migrations, especially Chapter Four. 